\title{
Arbuscular Mycorrhizal Fungi in the Phytostabilization of Soil Degraded by Manganese Mining
}

\author{
Kaio Gráculo Vieira Garcia ${ }^{1}$, Vânia Felipe Freire Gomes ${ }^{1}$, Paulo Furtado Mendes Filho ${ }^{1}$, \\ Claudia Miranda Martins ${ }^{1}$, José Maria Tupinambá da Silva Júnior ${ }^{1}$, Cleyton Saialy Medeiros Cunha ${ }^{1}$ \\ \& José Israel Pinheiro ${ }^{1}$ \\ ${ }^{1}$ Federal University of Ceará, Fortaleza, CE, Brazil \\ Correspondence: Kaio Gráculo Vieira Garcia, Federal University of Ceará, Fortaleza, CE, Brazil. E-mail: \\ kaiovieira88@hotmail.com
}

Received: August 9, 2018

doi:10.5539/jas.v10n12p192
Accepted: September 17, 2018

Online Published: November 15, 2018

URL: https://doi.org/10.5539/jas.v10n12p192

\begin{abstract}
Mining and processing of manganese $(\mathrm{Mn})$ minerals are activities that may result in the generation of large amounts of wastes and serious environmental impacts. Several strategies have been employed to remediate areas with high Mn concentrations, but many of them imply high investments and high risk of secondary pollution. This study aimed to evaluate the phytostabilization potential of Mimosa caesalpiniaefolia Benth. in Mn mining soil influenced by inoculation with arbuscular mycorrhizal fungi (AMF). The experimental design was completely randomized, with four treatments [not inoculated (control), inoculated with Rhizophagus clarus; inoculated with Claroideoglomus etunicatum and inoculated with Rhizophagus clarus + Claroideoglomus etunicatum (Mix)], and four replicates. Inoculation with Mix and C. etunicatum had higher efficiency in protecting plants against excess $\mathrm{Mn}$, due to the greater retention of this element in the roots and lower translocation to the shoots. Inoculation with $R$. clarus did not influence plant development and reduction of Mn contents in the shoots. The association of the AMF Mix and C. etunicatum with the species Mimosa caesalpiniaefolia Benth. enhances Mn phytostabilization in mining soils with high concentration of this element. The use of multivariate analyses proved to be an important tool with respect to the behavior of biometric, chemical and microbiological variables in mining soil with high Mn concentration.
\end{abstract}

Keywords: heavy metals, revegetation, microorganisms

\section{Introduction}

Mining and processing of manganese $(\mathrm{Mn})$ minerals are activities that may result in the generation of large quantities of wastes and serious environmental impacts. Improper management of this material can result in its dispersion on soil surface by runoff and or it may even reach groundwaters through leaching.

Mn is considered as an essential metal micronutrient but, when in excess, it can be considered as highly toxic to most living organisms (Chen, Yan, Sun, Tian, \& Liao, 2016; Mattison et al., 2017). In the case of plants, high Mn concentrations can delay growth and cause symptoms of chlorosis and necrosis, besides interrupting essential metabolic processes such as absorption, translocation and utilization of essential elements (Yang et al., 2015a).

Various strategies have been employed to remediate areas with high Mn concentrations, for instance the use of physical and chemical methods. Nonetheless, such strategies involve high investments, deterioration of soil quality and high risk of secondary pollution (Yang et al., 2013). Phytostabilization is a technique of phytoremediation based on the immobilization of the metal contaminating the soil through its absorption and accumulation inside or outside the root (Brancher \& Rogrigues, 2010), thus reducing its mobility and entry into the food chain.

In this context, inoculation with arbuscular mycorrhizal fungi (AMF) is considered as an important strategy in the reestablishment of plants with this purpose, given their capacity to increase the absorption of water and nutrients and to act in the reduction of the availability of metals to the host plant by different mechanisms.

These mechanisms include: dilution in tissues of plants due to their growth (Christie, Li, \& Chen, 2004; Schneider, Labory, Rangela, Alves, \& Guilherme, 2013), reduction in absorption of metals due to retention and immobilization in certain fungal structures and mycorrhized roots (Gonzalez-Chavez, D'Haen, Vangronsveld, \& Dodd, 2002), chelation of metals by compounds secreted by AMF, such as glomalin (Vodnik, Grčman, Maček, 
van Elteren, \& Kovačevič, 2008; Leung et al., 2013), chelating agents in the cytosol including the use of metallothioneins (plants and fungi), which are metal-binding proteins synthesized in a wide range of organisms exposed to toxic concentrations of metals (Kumar, Dayananda, \& Subramanyam, 2005; Cabral, Soares, Giachini, \& Siqueira, 2015), accumulation in plant vacuoles and fungal cells (Bertolazi et al., 2010) and temporary immobilization due to the transport by the hyphae (Carneiro, Siqueira, \& Moreira, 2001). Given the above, this study aimed to evaluate the phytostabilization potential of Mimosa caesalpiniaefolia Benth. in Mn mining soil influenced by inoculation with AMF.

\section{Material and Methods}

The experiment was carried out in greenhouse at the Department of Soil Science (DCS) of the Federal University of Ceará (UFC), located at the Pici Campus, Fortaleza, Ceará, Brazil ( $3^{\circ} 45^{\prime} 47^{\prime \prime}$ S; $38^{\circ} 31^{\prime} 23^{\prime \prime}$ W, at mean altitude of $47 \mathrm{~m}$ ). The climate of the region is classified as hot tropical, with mean annual temperature and rainfall of $27^{\circ} \mathrm{C}$ and $1600 \mathrm{~mm}$, respectively, characterized as Aw' based on Köppen's classification.

The experimental design was completely randomized, with four treatments of inoculation [control - not inoculated, Rhizophagus clarus; Claroideoglomus etunicatum and R. clarus + C. etunicatum (Mix)] and four replicates.

The soil used in the experiment was collected in the $0-20 \mathrm{~cm}$ layer in an area of Mn mining exploitation located in the municipality of Ocara, Ceará, Brazil. After collection, the soil was sieved through a 4-mm mesh to remove coarser particles, and then autoclaved at $121{ }^{\circ} \mathrm{C}$ at $1 \mathrm{~atm}$ pressure for $2 \mathrm{~h}$, to eliminate the native microbiota. Then, soil chemical characteristics were determined by the Laboratory of Soil and Water Routine Analysis of UFC, following the methodological references of EMBRAPA (2009) (Table 1).

Table 1. Chemical characteristics of the soil in the Mn mineral exploration area located in Ocara-CE, Brazil, used to cultivate $M$. caesalpiniaefolia Benth

\begin{tabular}{|c|c|c|c|c|c|c|c|c|c|c|c|c|c|c|}
\hline $\mathrm{pH}$ & $\mathrm{Al}$ & $\mathrm{Ca}$ & $\mathrm{Mg}$ & $\mathrm{Na}$ & $\mathrm{K}$ & $\mathrm{S}$ & $\mathrm{H}+\mathrm{Al}$ & $\mathrm{P}$ & $\mathrm{N}$ & OM & $\mathrm{Mn}$ & $\mathrm{Fe}$ & $\mathrm{Cu}$ & $\mathrm{Zn}$ \\
\hline$\left(\mathrm{H}_{2} \mathrm{O}\right)$ & \multicolumn{7}{|c|}{ 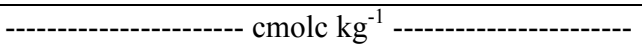 } & $\mathrm{mg} \mathrm{kg}^{-1}$ & \multicolumn{2}{|c|}{---- $\mathrm{g} \mathrm{kg}^{-1}$---- } & \multicolumn{4}{|c|}{------------ $\mathrm{mg} \mathrm{kg}^{-1}$----------. } \\
\hline 4.95 & 0.2 & 1.4 & 1.2 & 0.12 & 0.15 & 2.87 & 4 & 2.9 & 0.28 & 3.93 & 425.8 & 82.81 & 2.39 & 2.91 \\
\hline
\end{tabular}

The soil was distributed in pots with capacity for $5 \mathrm{~kg}$ (4 kg of soil per pot), which received basal fertilization with $6.75 \mathrm{mg}$ of $\mathrm{N}, 25 \mathrm{mg}$ of $\mathrm{K}, 10 \mathrm{mg}$ of $\mathrm{P}$ and $7.5 \mathrm{mg}$ of Ca per kg of substrate. The sources for the nutrients used were: $\mathrm{NH}_{2} \mathrm{CONH}_{2}, \mathrm{KCl}, \mathrm{Ca}\left(\mathrm{H}_{2} \mathrm{PO}_{4}\right)_{2} \cdot \mathrm{H}_{2} \mathrm{O}$ and $\mathrm{CaSO}_{4}$, respectively.

Mimosa caesalpiniaefolia Benth. seedlings were produced on polystyrene trays, by placing two seeds per cell at $2 \mathrm{~cm}$ depth. The substrate used consisted of washed sand, autoclaved at $121^{\circ} \mathrm{C}$ and $1 \mathrm{~atm}$ pressure for $2 \mathrm{~h}$. At 11 days after sowing, thinning was carried out in each cell, leaving only the most vigorous plant. At transplantation to the plastic pots, the seedlings were inoculated with $40 \mathrm{~g}$ of soil-inoculum containing spores and fragments of corn (Zea mays L.) roots colonized by the AMF species Rhizophagus clarus and Claroideoglomus etunicatum, separately and in a mixture (Mix).

The AMF isolates used in this experiment came from the Inoculum Bank of the Soil Microbiology Sector of UFC. The inoculum was placed at approximately $4 \mathrm{~cm}$ below the substrate surface. At inoculation, the soil-inoculum used had approximately 258,437 and 349 spores in $40 \mathrm{~g}$ of soil for the treatment with $R$. clarus, $C$. etunicatum and Mix (R. clarus $+C$. etunicatum), respectively. In order to reestablish the microbial community in the substrate, the substrate received $8 \mathrm{~mL}$ of a "filtrate" from the same soil used in the experiment (not autoclaved), without the presence of AMF propagules.

Plants were kept in the greenhouse and irrigated daily along the entire experimental period, which lasted 60 days. At the end of the experiment, plant shoots were cut close to the substrate and the material was then identified, placed in paper bags and dried in a forced-air oven at temperature of approximately $65{ }^{\circ} \mathrm{C}$, to obtain shoot dry matter. Roots were removed from the substrate, washed with tap water and dried following the same sequence used for the shoots. After obtaining shoot and root dry matter, the material was ground in a Wiley-type mill to determine the contents of phosphorus $(\mathrm{P})$ in the shoots and manganese $(\mathrm{Mn})$ in the shoots and roots, which were determined after nitric-perchloric digestion. $\mathrm{P}$ was analyzed by colorimetry and $\mathrm{Mn}$ by atomic absorption spectrophotometer.

The density of AMF spores after seedlings' growth was determined through the extraction of $100 \mathrm{~g}$ of soil by wet sieving from each sample of the treatments, following the procedures described by Gerdemann and Nicholson 
(1963). To evaluate mycorrhizal colonization, roots were washed in running water and placed in a container with $70 \%$ alcohol solution. Roots were cleared and stained for analysis of colonization according to the methodology adapted by Koske and Gemma (1989). Colonization percentage was obtained according to McGonigle et al. (1990).

The data were subjected to analysis of variance by F test $(p \leq 0.05)$, and means were compared by Scott-Knott test $(p \leq 0.05)$, using the statistical program ASSISTAT, Beta version 7.7 (Silva \& Azevedo, 2016). Additionally, cluster and principal component analyses were carried out using the program STATISTICA, version 7.0 (STATSOFT, 2004).

\section{Results and Discussion}

According to the analysis of variance (Table 2), the inoculation of $M$. caesalpiniaefolia Benth. plants with AMF significantly influenced $(p \leq 0.01)$ shoot and root dry matter, AMF spore density in soil, arbuscular mycorrhizal colonization, $\mathrm{P}$ content in the shoots and $\mathrm{Mn}$ contents in shoots and roots.

Table 2. Results of the analysis of variance (ANOVA) for the variables shoot dry matter (SDM), root dry matter (RDM), AMF spore density in soil (SpD), mycorrhizal colonization (MC), phosphorus content in the shoots (P) and manganese contents in the shoots (Mn Shoot) and roots (Mn Root)

\begin{tabular}{llllll}
\hline Variables & Units & $\mathrm{MS}^{1}$ & $\mathrm{CV}(\%)^{2}$ & $\mathrm{AO}^{3}$ & $\mathrm{~F}$ test \\
\hline SDM & $\left(\mathrm{g} \mathrm{plant}^{-1}\right)$ & 54.08 & 17.43 & 3.6 & $136.62^{* *}$ \\
RDM & $\left(\mathrm{g} \mathrm{plant}^{-1}\right)$ & 12.82 & 15.67 & 1.64 & $192.26^{* *}$ \\
SpD & $\left(100 \mathrm{~g}^{-1}\right.$ soil $)$ & 441894.75 & 22.63 & 399.37 & $50.42^{* *}$ \\
MC & $(\%)$ & 1911.89 & 22.03 & 21.59 & $84.52^{* *}$ \\
P & $\left(\mathrm{g} \mathrm{kg}^{-1}\right)$ & 0.07 & 10.45 & 0.65 & $15.38^{* *}$ \\
Mn Shoot & $\left(\mathrm{mg} \mathrm{kg}^{-1}\right)$ & 7682.41 & 4.53 & 1027.59 & $3.54^{* *}$ \\
Mn Root & $\left(\mathrm{mg} \mathrm{kg}^{-1}\right)$ & 82469102.93 & 7.53 & 8262.65 & $212.95^{* *}$ \\
\hline
\end{tabular}

Note. ${ }^{1}$ Medium square; ${ }^{2}$ Coefficient of variation; ${ }^{3}$ Average Overall; **, *, ns: significant by the $\mathrm{F}$ test at the level of $1 \%$ and $5 \%$ of significance and not significant, respectively.

Mimosa caesalpiniaefolia Benth. plants inoculated with the AMF, Mix and C. etunicatum, showed significant increases of $29.1 \%$ and $25.2 \%$, respectively, in shoot dry matter (SDM) compared with non-inoculated plants (Figure 1A). Similar response was also observed for root dry matter (RDM), where inoculation with the AMF Mix followed by $C$. etunicatum led to significant increases of $26 \%$ and $16.5 \%$, respectively, compared with non-inoculated plants (Figure 1B).
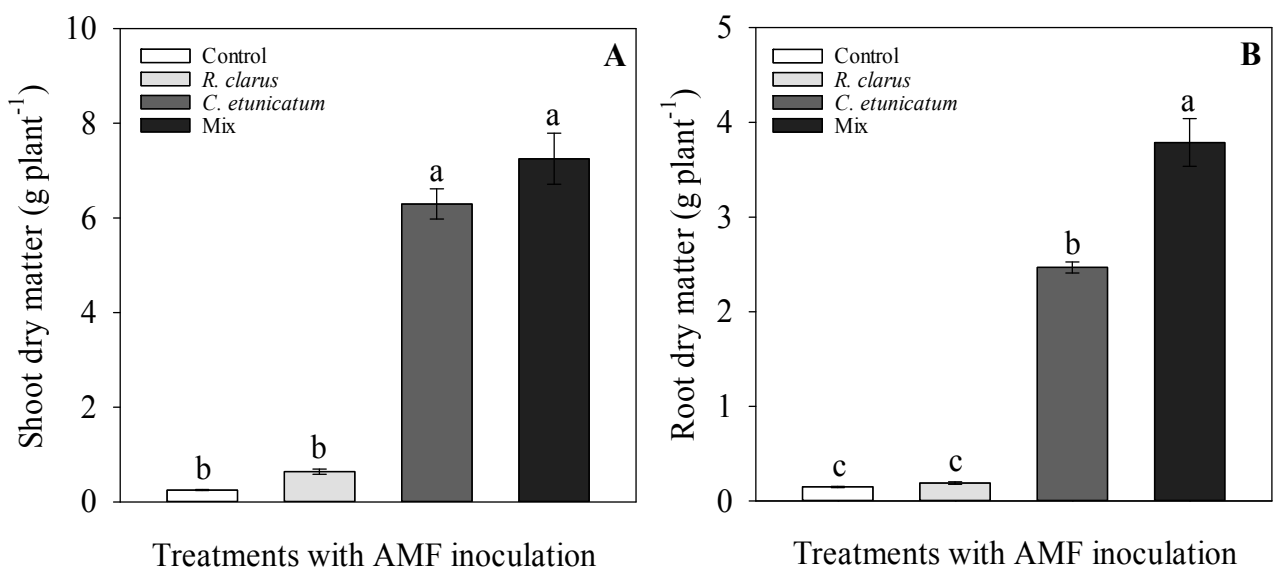

Figure 1. Shoot dry matter (SDM) and root dry matter (RDM) as a function of different treatments with AMF inoculation in M. caesalpiniaefolia Benth. plants grown in Mn mining soil. The values represent the mean of four replicates \pm standard error. Means followed by equal letters do not differ by Scott-Knott test $(\mathrm{p} \leq 0.05)$ 
Enhancement in nutrient absorption from the soil solution and protection of plants against toxicity by heavy metals are benefits caused by the AMF which are related to the greater growth, generally in terms of dry matter, in mycorrhized plants (Carrenho, Alves, \& Santos, 2018; Gunathilakae, Yapa, \& Hettiarachchi, 2018). Li, Sun, Jiang, Chen, and Zhang (2018), studying the attenuation of toxicity by arsenic in Medicago sativa plants colonized by AMF, reported significant increase in shoot and root dry matter of mycorrhized plants at all levels of arsenic. Similar responses of inoculation with AMF have also been observed by Nogueira, Nehls, Hampp, Poralla, and Cardoso (2007) in soybean plants grown in soil with high Mn content and by Garcia et al. (2017) in Mimosa caesalpiniaefolia Benth. plants grown in soil degraded by Mn mining.

AMF spore density in soil was significantly higher in the rhizosphere of plants inoculated with $C$. etunicatum, followed by the treatment Mix, compared with the rhizosphere of plants inoculated with R. clarus (Figure 2A).
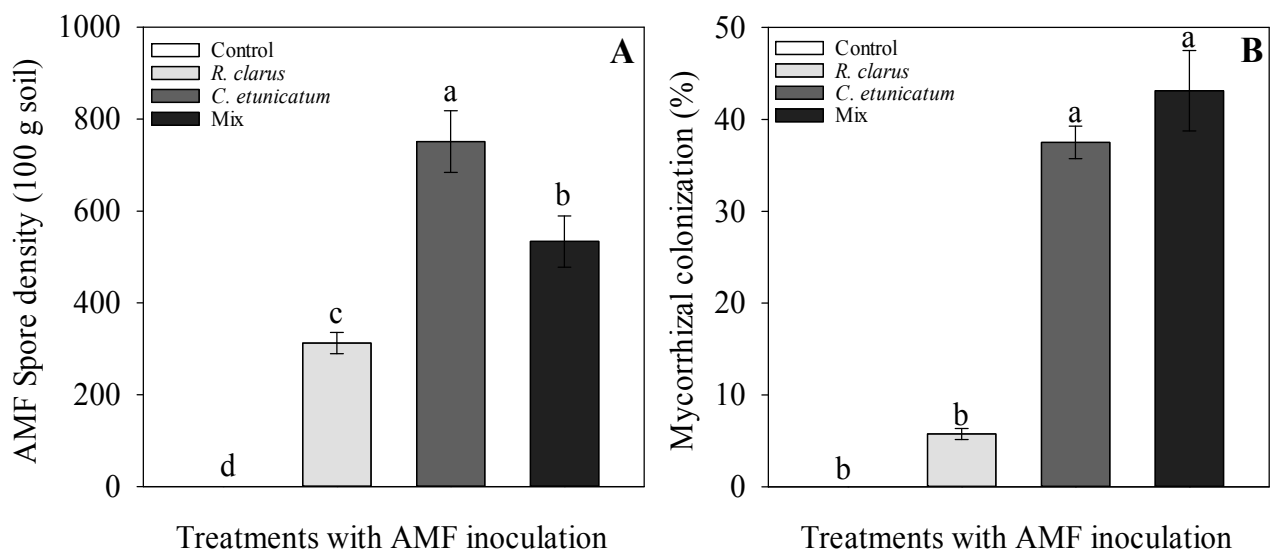

Figure 2. AMF spore density $(\mathrm{SpD})$ and arbuscular mycorrhizal colonization $(\mathrm{MC})$ as a function of different treatments with AMF inoculation in M. caesalpiniaefolia Benth. plants grown in Mn mining soil. The values represent the mean of four replicates \pm standard error. Means followed by equal letters do not differ by Scott-Knott test $(\mathrm{p} \leq 0.05)$

The number of AMF spores in soil has been a parameter widely used by researchers to evaluate the effect of heavy metals on AMF (Rivera-Becerril et al., 2013; Schneider, Bundschuh, Rangel, \& Guilherme, 2017; Garcia et al., 2017). A series of limitations, such as the reduction in spore germination, extraradical mycelium development and sporulation of some AMF species, has been reported in the presence of excess heavy metals in the soil (Pawlowska \& Charvat, 2004; Yang et al., 2015b). Cardoso, Navarro, and Nogueira (2002), working with Mn and in vitro germination of AMF spores, concluded that AMF spore germination was differently damaged between species and $\mathrm{Mn}^{2+}$ doses. On the other hand, in soil contaminated by cadmium, Martins, R. Melloni, and E. G. P. Melloni (2017) reported different behavior between AMF species at the different doses of this element, thus demonstrating higher tolerance of some AMF to the excess of this metal. In areas of lead and zinc mining, Yang et al. (2015b) observed variation from 46 to 670 spores in $100 \mathrm{~g}$ of soil, in soil with higher and lower levels, respectively, of contamination by these metals.

Regarding arbuscular mycorrhizal colonization, plants inoculated with $C$. etunicatum and Mix had the highest percentages of colonized roots, $37.5 \%$ and $43.12 \%$, respectively (Figure 2B). There were no spores or signs of root colonization in plants of the control treatment, thus indicating the absence of contamination. Variations in the responses of mycorrhizal colonization by different AMF species in the same plant grown in soil with excess of heavy metals have already been evidenced in several studies (Schneider et al., 2017; Li et al., 2017; Spagnoletti, Carmona, Gómez, Chiocchio, \& Lavado, 2017; Brito, Carvalho, Alho, \& Goss, 2014). In the present study, it is also possible to observe that the same treatments of inoculation with AMF (C. etunicatum and Mix) which had positive effect on plant development were also responsible for the highest percentages of mycorrhizal colonization. The effects of AMF on plant development depend on fungal isolate, plant species and heavy metals involved in the association (Ferrol, Tamayo, \& Vargas, 2016). In addition, the data of the present study also allow to state that there may have been a synergistic effect of the treatment Mix, when both symbionts were inoculated together, resulting in higher percentage of mycorrhizal colonization and other benefits, as also reported by Tian, Drijber, Li, Miller, and Wienhold (2013). 
As to the P contents in the shoots (Table 3), inoculation with $C$. etunicatum followed by the treatment Mix caused significant increments of $47.3 \%$ and $17.5 \%$, respectively, in this variable, compared with non-inoculated plants. In general, mycorrhized plants had higher $\mathrm{P}$ contents than non-mycorrhized plants.

Table 3. Phosphorus contents in the shoots as a function of different treatments with AMF inoculation in $M$. caesalpiniaefolia Benth. plants grown in Mn mining soil

\begin{tabular}{lccc}
\hline \multicolumn{4}{c}{ Treatments with AMF inoculation } \\
\hline Control & R. clarus & C. etunicatum & Mix \\
\hline$-0.57 \pm 0.03 \mathrm{c}$ & $0.54 \pm 0.01 \mathrm{c}$ & $0.84 \pm 0.04 \mathrm{a}$ & $0.67 \pm 0.03 \mathrm{~b}$ \\
\hline
\end{tabular}

Note. The values represent the mean of four replicates \pm standard error. Means followed by equal letters do not differ by Scott-Knott test $(\mathrm{p} \leq 0.05)$.

This fact is related to the larger soil volume explored by the AMF hyphae, which work as an extension of the root system (Folli-Pereira, Meira-Haddad, Bazzolli, \& Kasuya, 2012). Under adequate nutrition with P, plants may exhibit higher vigor and capacity to withstand the negative effects caused by the excess Mn (Nogueira et al., 2007). According to Foy (1984), the formation of low-solubility complexes between $P$ and Mn may act in the reduction of toxicity by Mn. Our results also corroborate those found by Zhou et al. (2017), and Sadia, Asma, and Riffat (2016).

Mn contents in the shoots decreased significantly in plants inoculated with AMF, compared with non-inoculated plants, except for the treatment with R. clarus (Figure 3). On the other hand, Mn contents in the roots were significantly higher in plants inoculated with AMF, except for $R$. clarus (Figure 3).

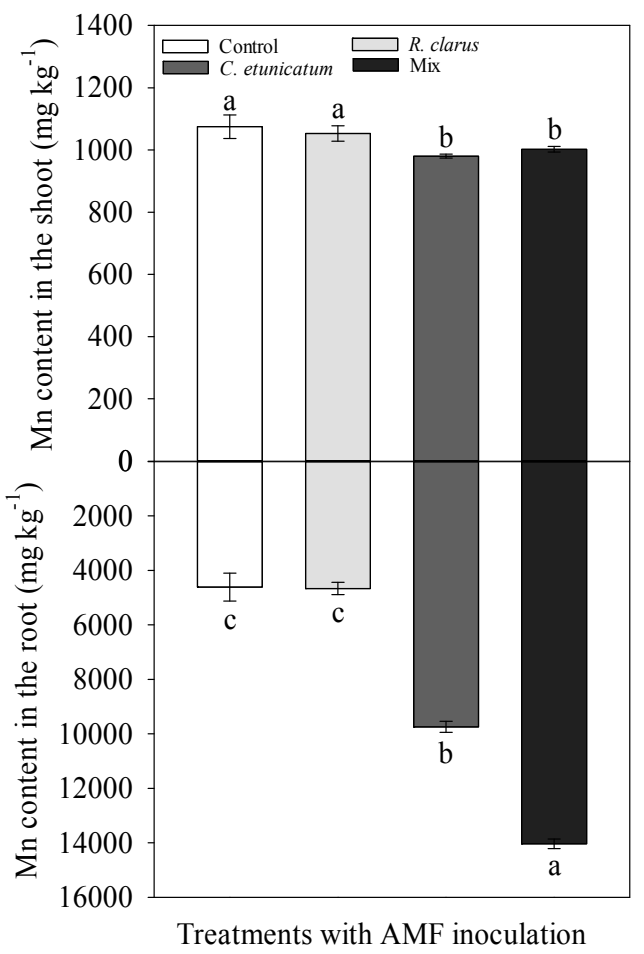

Figure 3. Manganese contents in the shoots and roots as a function of different treatments with AMF inoculation in M. caesalpiniaefolia Benth. plants grown in Mn mining soil. The values represent the mean of four replicates \pm standard error. Means followed by equal letters do not differ by Scott-Knott test $(p \leq 0.05)$

Mimosa caesalpiniaefolia Benth. plants inoculated with AMF had mean Mn content of $1074.86 \mathrm{mg} \mathrm{kg}^{-1}$, which is above the levels considered as toxic for this metal $\left(\mathrm{Mn}=400 \mathrm{mg} \mathrm{kg}^{-1}\right.$ in shoot dry matter) (Kabata-Pendias \& 
Pendias, 2001; Foy, Chaney, \& White, 1978). However, although the inoculation with C. etunicatum and Mix reduced $\mathrm{Mn}$ contents in the shoots, compared with non-inoculated plants, these contents were still very high (980.29 to $1002.21 \mathrm{mg} \mathrm{kg}^{-1}$ ) and above the range considered as toxic for plant species in general (Kabata-Pendias \& Pendias, 2001). In spite of that, colonized plants did not exhibit symptoms of toxicity. It has been demonstrated that mycorrhizal colonization and tolerance of AMF to heavy metals have shown high variability, resulting from both AMF species and host plant (Liu et al., 2015). Frequently, mycorrhization in some plants has led to higher contents of metals in the roots and lower contents in the shoots (Ferrol et al., 2016; Wu et al., 2016; Gunathilakae et al., 2018). In the present study, we also observed that plants colonized by C. etunicatum and Mix showed higher $\mathrm{Mn}$ contents in the roots than in the shoots. The reason for this response can be related to the capacity of arbuscular mycorrhizae to retain and immobilize metals in certain fungal structures and colonized roots (Gonzalez-Chavez et al., 2002). However, a more detailed investigation using scanning electron microscopy associated with X-ray microanalysis would be necessary to clarify such hypothesis. The obtained results also confirm the potential of the species M. caesalpiniaefolia Benth., mainly when associated with the AMF, to act as phytostabilizing plant in areas of Mn mining.

The responses of cluster analysis illustrated by the dendrogram (Figure 4) allow the identification of two main groups which describe the interactions between the and biometric, chemical and microbiological variables of the present study: Group 1, containing only Mn Shoot, and Group 2, including SDM, RDM, MC, SpD, P and Mn Root.

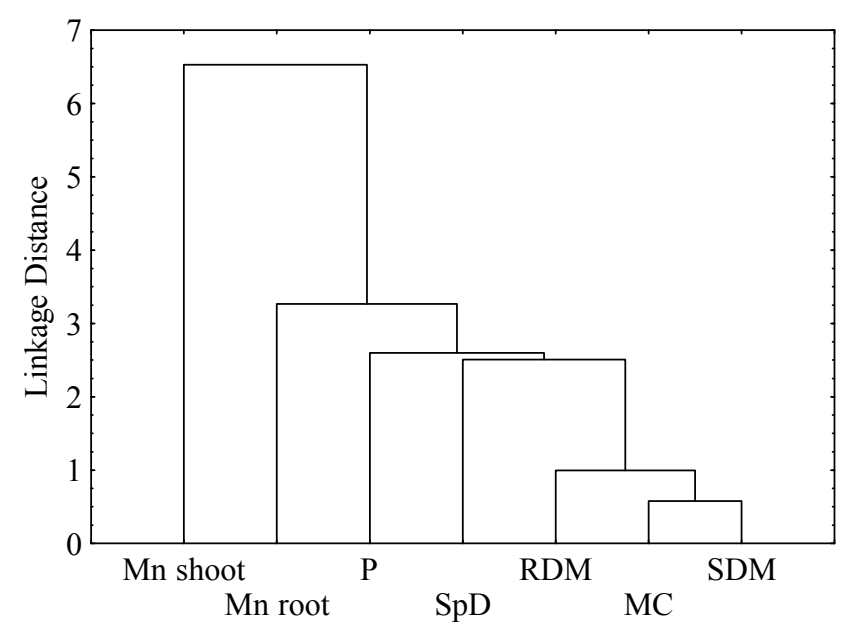

Figure 4. Dendrogram for the 7 variables (Mn Shoot, Mn Root, P, SpD, RDM, MC, SDM) analyzed as a function of different treatments with AMF inoculation in M. caesalpiniaefolia Benth. plants grown in Mn mining soil

The method most used to extract factors in factor analysis is the principal component (PCA) method. It is used to reduce the number of variables in order to obtain a lower number of factors necessary to explain as much as possible the variance represented by the original variables (Ho, 2006).

The variables composing the principal components (PC) were selected based on the homogeneity and heterogeneity of the groups identified in the Cluster Analysis. In this context, no variable was disregarded for having short linkage distances and, therefore, high intensities of correlation. Thus, the PCA was conducted in the data matrix composed of 7 variables. According to Vicini (2005), the selection of the number of components can take into account different criteria, and a very important one is the Kaiser's or latent root criterion, which selects only the factors with eigenvalues higher than 1 (one).

Based on this premise, two components with eigenvalues above 1 (one) were extracted and together explained about $83.62 \%$ of the total data variability (Table 4 ). 
Table 4. Extraction of the principal components for biometric (SDM, RDM), chemical (P, Mn Shoot and Mn Root) and microbiological (MC and $\mathrm{SpD}$ ) values and their respective eigenvalues, total variance and cumulative variance

\begin{tabular}{lll}
\hline Variables & Factor 1 & Factor 2 \\
\hline SDM & 0.96066 & 0.24911 \\
RDM & 0.90651 & 0.38035 \\
MC & 0.93986 & 0.32475 \\
SpD & 0.88808 & -0.18755 \\
P & 0.81311 & -0.42117 \\
Mn Shoot & -0.74547 & 0.14285 \\
Mn Root & 0.73133 & -0.37442 \\
\hline Eigenvalues & 5.16834 & 1.10000 \\
Total variance (\%) & 73.8335 & 9.79058 \\
Cumulative variance (\%) & 73.8335 & 83.62400 \\
\hline
\end{tabular}

The rotated matrix of the components containing the factor loadings shows the degree of correlation existing between the variables and the principal component 1 (PC1). The rule generally adopted is that the minimum value for the loadings is 0.30 , but loadings with values above 0.5 are the significant ones (Hair, Anderson, Tatham, \& Black, 2005).

The correlations between the studied variables and PC1 were: SDM (0.960657), MC (0.939855), RDM (0.906511), SpD (0.888075), P (0.813111) and Mn Root (0.731332); for Mn Shoot (-0.745465) the sign of the loading was negative, indicating that the correlation is inversely proportional, i.e., as the quantitative values of $\mathrm{SDM}, \mathrm{MC}$, RDM, SpD, P, Mn Root, in this order of importance, increase, there is a reduction in Mn Shoot values. The total variance explained by PC1 was $73.83 \%$, that is, $73.83 \%$ of the behavior of the variables is being retained by the factor (Table 4).

The results obtained in the analysis of all variables support the hypothesis that the reduction in Mn content in the shoots of plants colonized by AMF is related to its higher accumulation in the roots. This again reinforces the role of AMF in enhancing the tolerance of Mimosa caesalpiniaefolia Benth. plants and favoring their development in Mn mining soil. Similar results with AMF have also been observed by Nogueira et al. (2007) in Glycine max L. Merrill plants grown in soil with excess Mn and by Hristozkova et al. (2016) in Calendula officinalis L. plants grown in soil contaminated with cadmium and lead.

Although the second principal component (PC2) showed eigenvalues above 1 and explained 9.27\% of the total variability, its correlations were considered as low $(\mathrm{R}<0.5)$ (Table 4$)$, and were inexpressive to explain the interaction existing between the analyzed variables. However, some studies found in the literature use correlations from 0.3 to explain the data. The present study evaluated correlations between variables higher than or equal to 0.5 . The explanation for the low interaction between variables in PC2 is related to the high variability explained in PC1 (Figure 5). 


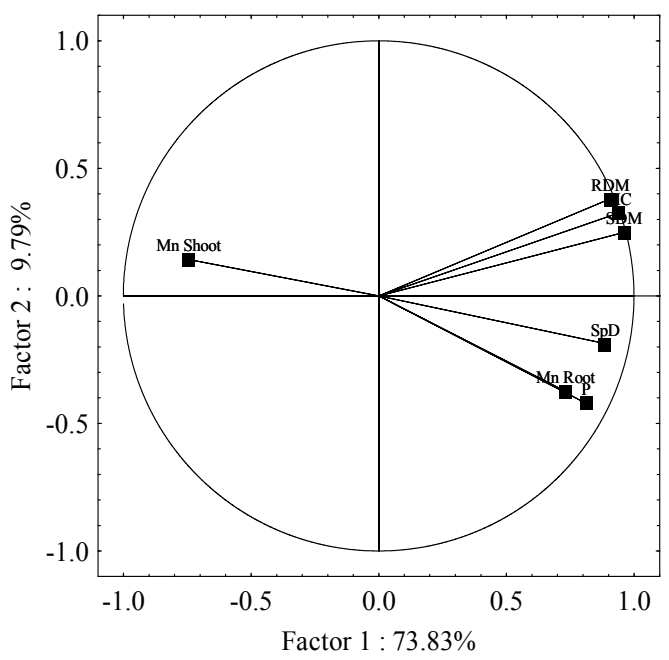

Figure 5. Two-dimensional projection (Biplot) of biometric, chemical and microbiological variables evaluated in the first two principal components

\section{Conclusions}

The association of the AMF Mix and Claroideoglomus etunicatum with the species Mimosa caesalpiniaefolia Benth. enhances Mn phytostabilization in mining soils with high concentration of this element.

Further research is necessary to study the capacity of Mimosa caesalpiniaefolia Benth. plants associated with AMF to develop under field conditions.

Approaches using multivariate analyses are important tools to provide more in-depth knowledge on the behavior of biometric, chemical and microbiological variables in mining soil with high concentration of manganese.

\section{References}

Bertolazi, A. A., Canton, G. C., Azevedo, I. G., Cruz, Z. M., Soares, D. N., Conceição, J. M., ... Ramos, A. C. (2010). O papel das ectomicorrizas na biorremediação dos metais pesados no solo. Natureza On-line, 8, 24-31.

Branches, A. M. B., \& Rodrigues, V. M. (2010). Análise da fitorremediação como método de recuperação de áreas degradadas pela mineração. Congresso Brasileiro de Mina a Céu Aberto, 6. Anais ... Belo Horizonte: VI Congresso Brasileiro de Mina a Céu Aberto.

Brito, I., Carvalho, M., Alho, L., \& Goss, M. J. (2014). Managing arbuscular mycorrhizal fungi for bioprotection: Mn toxicity. Soil Biology and Biochemistry, 68, 78-84. https://doi.org/10.1016/j.soilbio.2013.09.018

Cabral, L., Soares, C. R. F. S., Giachini, A. J., \& Siqueira, J. O. (2015). Arbuscular mycorrhizal fungi in phytoremediation of contaminated areas by trace elements: Mechanisms and major benefits of their applications. World Journal of Microbiology and Biotechnology, 31, 1655-1664. https://doi.org/10.1007/ s112 74-015-1918-y

Cardoso, E. J. B. N., Navarro, R. B., \& Nogueira, M. A. (2002). Manganês e germinação de esporos de fungos micorrízicos arbusculares in vitro. Revista Brasileira de Ciência do Solo, 26, 795-799. https://doi.org/ $10.1590 / \mathrm{S} 0100-06832002000300025$

Carneiro, M. A. C., Siqueira, J. O., \& Moreira, F. M. S. (2001). Estabelecimento de plantas herbáceas em solo com contaminação de metais pesados e inoculação de fungos micorrízicos arbusculares. Pesquisa Agropecuária Brasileira, 36, 1443-1452. https://doi.org/10.1590/S0100-204X2001001200001

Carrenho, R., Alves, L. de J., \& Santos, I. da S. (2018). Arbuscular Mycorrhizal Fungi, Interactions with Heavy Metals and Rehabilitation of Abandoned Mine Lands. Bio-geotechnologies for Mine Site Rehabilitation, [s.I.], 261-279. https://doi.org/10.1016/B978-0-12-812986-9.00015-4

Chen, Z., Yan, W., Sun, L., Tian, J., \& Liao, H. (2016). Proteomic analysis reveals growth inhibition of soybean roots by manganese toxicity is associated with alteration of cell wall structure and lignification. Journal of Proteomics, 143, 151-160. https://doi.org/10.1016/j.jprot.2016.03.037 
Christie, P., Li, X., \& Chen, B. (2004). Arbuscular mycorrhiza can depressa translocation of zinc to shoots of host plants in soils moderately polluted with zinc. Plant and Soil, 261, 209-217. https://doi.org/10.1023/ B:PLSO.0000035542.79345.1b

EMBRAPA (Empresa Brasileira de Pesquisa Agropecuária). (2009). Manual de análises químicas de solos, plantas e fertilizantes (p. 370). Embrapa Informação Tecnológica.

Ferrol, N., Tamayo, E., \& Vargas, P. (2016). The heavy metal paradox in arbuscular mycorrhizas: From mechanisms to biotechnological applications. Journal of Experimental Botany, 67, 6253-6265. https://doi.org/10.1093/jxb/erw403

Folli-Pereira, M. da S., Meira-Haddad, L. S., Bazzolli, D. M. S., \& Kasuya, M. C. M. (2012). Micorriza arbuscular e a tolerância das plantas ao estresse. Revista Brasileira de Ciência do Solo, 36, 1663-1679. https://doi.org/10.1590/S0100-06832012000600001

Foy, C. D. (1984). Physiological effects of hydrogen, aluminium, and manganese toxicities in acid soils. In F. Adams (Ed.), Soil Acidity and Liming (pp. 57-97). American Society of Agronomy, Madison.

Foy, C. D., Chaney, R. L., \& White, M. C. (1978). The physiology of metal toxicity in plants. Annual Review of Plant Physiology, 29, 511-566. https://doi.org/10.1146/annurev.pp.29.060178.002455

Garcia, K. G. V., Freire Gomes, V. F., Mendes Filho, P. F., Martins, C. M., Almeida, A. M. M., \& Silva Júnior, J. M. T. da. (2017). Tolerância de Mimosa caesalpiniaefolia Benth. associada a micorrizas arbusculares em substrato da mineração de manganês. Revista de Ciências Agrarias-Amazon Journal of Agricultural and Environmental Sciences, 60, 247-255.

Gerdemann, J. W., \& Nicolson, T. H. (1963). Spores of mycorrhizae Endogone species extracted from soil by wet sieving and decanting. Transactive British Mycology Society, 388, 235-244. https://doi.org/10.1016/ S0007-1536(63)80079-0

Gonzalez-Chavez, C., D’Haen, J., Vangronsveld, J., \& Dodd, J. C. (2002). Copper sorption and accumulation by the extraradical mycelium of different Glomus spp. (arbuscular mycorrhizal fungi) isolated from the same polluted soil. Plant and Soil, 240, 287-297. https://doi.org/10.1023/A:1015794622592

Gunathilakae, N., Yapa, N., \& Hettiarachchi, R. (2018). Effect of arbuscular mycorrhizal fungi on the cadmium phytoremediation potential of Eichhornia crassipes (Mart.) Solms. Groundwater for Sustainable Development, S., 1-6.

Hair Jr., J. F., Anderson, R. E., Tatham, R. L., \& Black, W. C. (2005). Análise multivariada de dados (5th ed., p. 583). Bookman, Porto Alegre.

Ho, R. (2006). Handbook of univariate and multivariate data analysis and interpretation with SPSS. CRC Press, New York. https://doi.org/10.1201/9781420011111

Hristozkova, M., Geneva, M., Stancheva, I., Boychinova, M., \& Djonova, E. (2016). Contribution of arbuscular mycorrhizal fungi in attenuation of heavy metal impact on Calendula officinalis development. Applied Soil Ecology, 101, 57-63. https://doi.org/10.1016/j.apsoil.2016.01.008

Kabata-Pendias, A., \& Pendias, H. (2001). Trace elements in soils and plants (p. 413). Boca Raton: CRC Press.

Koske R. E., \& Gemma, J. N. (1989). A modified procedure for staining roots to detect VA mycorrhizas. Mycological Research, 92, 486-505. https://doi.org/10.1016/S0953-7562(89)80195-9

Kumar, K. S., Dayananda, S., \& Subramanyam, C. (2005). Copper alone, but not oxidative stress, induces copper-metallothionein gene in Neurospora crassa. Fems Microbiology Letters, 242, 45-50. https://doi.org/ 10.1016/j.femsle.2004.10.040

Leung, H.-M., Wang, Z.-W., Ye, Z.-H., Yung, K.-L., Peng, X.-L., \& Cheung, C. (2013). Interactions Between Arbuscular Mycorrhizae and Plants in Phytoremediation of Metal-Contaminated Soils: A Review. Pedosphere, 23, 549-563. https://doi.org/10.1016/S1002-0160(13)60049-1

Li, J., Liang, H., Yanb, M., Chen, L., Zhang, H., Liu, J., Wang, S., \& Jina, Z. (2017). Arbuscular mycorrhiza fungi facilitate rapid adaptation of Elsholtzia splendens to copper. Science of the Total Environment, 599-600, 1462-1468. https://doi.org/10.1016/j.scitotenv.2017.05.063

Li, J., Sun, Y., Jiang, X., Chen, B., \& Zhang, X. (2018). Arbuscular mycorrhizal fungi alleviate arsenic toxicity to Medicago sativa by influencing arsenic speciation and partitioning. Ecotoxicology and Environmental Safety, 157, 235-243. https://doi.org/10.1016/j.ecoenv.2018.03.073 
Liu, H., Yuan, M., Tan, S., Yang, X., Lan, Z., Jiang, Q., Ye, Z., ... Jing, Y. (2015). Enhancement of arbuscular mycorrhizal fungus (Glomus versiforme) on the growth and $\mathrm{Cd}$ uptake by Cd-hyperaccumulator Solanum nigrum. Applied Soil Ecology, 89, 44-49. https://doi.org/10.1016/j.apsoil.2015.01.006

Martins, R. M. S., Melloni, R., \& Melloni, E. G. P. (2017). Crescimento micelial de fungos micorrízicos arbusculares e formação de micorriza em solo contaminado por cádmio. Scientia Agraria, 18, 48-60. https://doi.org/10.5380/rsa.v18i3.51122

Mattison, D. R., Milton, B., Krewski, D., Levy, L., Dorman, D. C., Agget, P. J., ... McGough, D. (2017). Severity scoring of manganese health effects for categorical regression. Neurotoxicology, 58, $203-216$. https://doi.org/10.1016/j.neuro.2016.09.001

McGonigle, T. P., Miller, M. H., Evans, D. G., Fairchild, G. L., \& Swan, J. A. (1990). A new method which gives an objective measure of colonization of roots by vesicular-arbuscular mycorrhizal fungi. New Phytologist, 115, 495-501. https://doi.org/10.1111/j.1469-8137.1990.tb00476.x

Nogueira, M. A., Nehls, U., Hampp, R., Poralla, K., \& Cardoso, E. J. B. N. (2007). Mycorrhiza and soil bacteria influence extractable iron and manganese in soil and uptake by soybean. Plant and Soil, 298, $273-284$. https://doi.org/10.1007/s11104-007-9379-1

Pawlowska, T. E., \& Charvat, I. (2004). Heavy-metal stress and developmental patterns of arbuscular mycorrhizal fungi. Applied and Environmental Microbiology, 70, 6643-6649. https://doi.org/10.1128/AEM. 70.11. 6643-6649.2004

Rivera-Becerril, F., Juárez-Vázquez, L. V., Hernández-Cervantes, S. C., Acevedo-Sandoval, O. A., Vela-Correa, G., Cruz-Chávez, E., Moreno-Espíndola, I. P., ... León-González, F. (2013). Impacts of manganese mining activity on the environment: Interactions among soil, plants, and arbuscular mycorrhiza. Archives of Environmental Contamination and Toxicology, 64, 219-227. https://doi.org/10.1007/s00244-012-9827-7

Sadia, K., Asma, B., \& Riffat, N. M. (2016). Role of arbuscular mycorrhizal fungi in phytoremediation of heavy metals and effects on growth and biochemical activities of wheat (Triticum aestivum L.) plants in $\mathrm{Zn}$ contaminated soils. African Journal of Biotechnology, 15, 872-883. https://doi.org/10.5897/AJB2016.15292

Schneider, J., Bundschuh, J., Rangel, W. de M., \& Guilherme, L. R. G. (2017). Potential of different AM fungi (native from As-contaminated and uncontaminated soils) for supporting Leucaena leucocephala growth in As-contaminated soil. Environmental Pollution, 224, 125-135. https://doi.org/10.1016/j.envpol.2017.01.071

Schneider, J., Labory, C. R. G., Rangela, W. M., Alves, E., \& Guilherme, L. R. G. (2013). Anatomy and ultrastructure alterations of Leucaena leucocephala (Lam.) inoculated with mycorrhizal fungi in response to arsenic-contaminated soil. Journal of Hazardous Materials, 262, 1245-1258. https://doi.org/10.1016/ j.jhazmat.2012.05.091

Silva, F. A. S., \& Azevedo, C. A. V. (2016). The Assistat Software Version 7.7 and its use in the analysis of experimental. African Journal of Agricultural Research, 11, 3733-3740. https://doi.org/10.5897/AJAR20 16.11522

Spagnoletti, F., Carmona, M., Gómez, N. E. T., Chiocchio, V., \& Lavado, R. S. (2017). Arbuscular mycorrhiza reduces the negative effects of M. phaseolina on soybean plants in arsenic-contaminated soils. Applied Soil Ecology, 121, 41-47. https://doi.org/10.1016/j.apsoil.2017.09.019

STATSOFT. (2004). Statistica 7.0 for Windows: Computer program manual. Tulsa, USA. Retrieved from http://www.statsoft.com

Tian H., Drijber, R. A., Li, X., Miller, D. N., \& Wienhold, B. J. (2013). Arbuscular mycorrhizal fungi differ in their ability to regulate the expression of phosphate transporters in maize (Zea mays L.). Mycorrhiza, 23, 507-514. https://doi.org/10.1007/s00572-013-0491-1

Vicini, L. (2005). Análise multivariada da teoria à prática. Monografia de Especialização (p 215). Santa Maria, Universidade Federal de Santa Maria. Retrieved from http://w3.ufsm.br/adriano/livro/Caderno\%20dedatic o\%20multivariada\%20-\%20LIVRO\%20FINAL\%201.pdf

Vodnik, D., Grčman, H., Maček, I., van Elteren, J. T., \& Kovačevič, M. (2008). The contribution of glomalin-related soil protein to $\mathrm{Pb}$ and $\mathrm{Zn}$ sequestration in polluted soil. Science of the Total Environment, 392, 130-136. https://doi.org/10.1016/j.scitotenv.2007.11.016 
Wu, S., Zhang, X., Chen, B., Wu, Z., Li, T., Hu, Y., Sun, Y., ... Wang, Y. (2016). Chromium immobilization by extraradical mycelium of arbuscular mycorrhiza contributes to plant chromium tolerance. Environmental and Experimental Botany, 122, 10-18. https://doi.org/10.1016/j.envexpbot.2015.08.006

Yang, Q., Zeng, Q., Xiao, F., Liu, X., Pan, J., He, J., \& Li, Z. (2013). Investigation of manganese tolerance and accumulation of two Mn hyperaccumulators Phytolacca americana L. and Polygonum hydropiper L. in the real Mn-contaminated soils near a manganese mine. Environmental Earth Sciences, 68, 1127-1134. https://doi.org/10.1007/s12665-012-1814-9

Yang, W., Ding, Z., Zhao, F., Wang, Y., Zhang, X., Zhu, Z., \& Yang, X. (2015a). Comparison of manganese tolerance and accumulation among 24 Salix clones in a hydroponic experiment: Application for phytoremediation. Journal of Geochemical Exploration, 149, 1-7. https://doi.org/10.1016/j.gexplo.2014. 09.007

Yang, Y., Liang, Y., Ghosh, A., Song, Y., Chen, H., \& Tang, M. (2015b). Assessment of arbuscular mycorrhizal fungi status and heavy metal accumulation characteristics of tree species in a lead-zinc mine area: Potential applications for phytoremediation. Environmental Science and Pollution Research, 22, 13179-13193. https://doi.org/10.1007/s11356-015-4521-8

Zhou, X., Fu, L., Xia, Y., Zheng, L., Chen, C., Shen, Z., \& Chen, Y. (2017). Arbuscular mycorrhizal fungi enhance the copper tolerance of Tagetes patula through the sorption and barrier mechanisms of intraradical hyphae. Metallomics, 9, 936-948. https://doi.org/10.1039/C7MT00072C

\section{Copyrights}

Copyright for this article is retained by the author(s), with first publication rights granted to the journal.

This is an open-access article distributed under the terms and conditions of the Creative Commons Attribution license (http://creativecommons.org/licenses/by/4.0/). 